\title{
IS JUSTICE SERVED BY DUE PROCESS?: AFFECTING THE OUTCOME OF SPECIAL EDUCATION HEARINGS IN PENNSYLVANIA
}

\author{
Peter J. KurilofF* \\ I \\ Introduction: The EAHCA, Due Process, and the \\ LEGALIZATION OF EDUCATION
}

The Education for All Handicapped Children Act of 1975 (EAHCA) ${ }^{1}$ has been described as the major piece of social legislation passed during the 1970 's. ${ }^{2}$ Certainly it represented a major step in what Kirp and Kirp called the legalization of education. ${ }^{3}$ Those who shaped the reform in Congress believed such a step was necessary to bring about a much needed reordering of priorities in education. ${ }^{4}$ Indeed, for those unaccustomed to dealing with a variety of seriously handicapping conditions, the extension of a right to a free, "appropriate" education in the "least restrictive environment" represented a radical departure from traditional practice. ${ }^{5}$

By now, anyone involved with elementary or secondary education is familiar with at least the gross outlines of the law. What is important to emphasize is its basically procedural nature. Essentially, the EAHCA established one set of procedures for giving substance to the right to education and another set to protect that right. Congress, through its definition of "appro-

\footnotetext{
Copyright (C) 1985 by Law and Contemporary Problems

* Associate Professor of Education, University of Pennsylvania. The research reported here was supported, in part, by a grant from the National Institute of Education (Project No. Neg. -003-0192). I wish to express my special appreciation for the steadfast support and excellent advice of the Project Officer, Mr. Ronald Anson. In addition, I would like to thank Professors Arthur Dole, William Buss, Katharine Bartlett, and Judith Wegner for their careful critiques of earlier drafts of this paper. Professor Paul McDermott was very helpful on statistical matters. My research assistant, Sara Wedeman, was also of much help. Finally, I want to thank my graduate student and colleague, Steven Goldberg, Esq., for his many substantive and editorial suggestions.

1. Pub. L. No. 94-142, 89 Stat. 773 (1975) (codified as amended at 20 U.S.C. $\S \S 1400-1461$ (1982)).

2. Pittenger \& Kuriloff, Educating the Handicapped: Reforming a Radical Law, 66 PuB. INTEREst 72 (1982).

3. Kirp \& Kirp, The Legalization of the School Psychologists' World, 14 J. Sch. Psychology 83 (1976).

4. Neal \& Kirp, The Allure of Legalization Reconsidered: The Case of Special Education, Law \& CoNTEMP. ProBs., Winter 1985, at 63.

5. See Pittenger \& Kuriloff, supra note 2; see also Kirp, Buss \& Kuriloff, Legal Reforms of Special Education: Empirical Studies and Procedural Proposals, 62 Calif. L. Rev. 40-155 (1974) (analysis of the early impact of those reforms which preceded and provided a model for the EAHCA).
} 
priate," does not guarantee any particular level of substantive education. ${ }^{6}$ Recognizing that such tasks could only be accomplished for individual children within specific contexts by trained professionals, Congress instead required an individualized education program (IEP) for each child. ${ }^{7}$ This requirement was reinforced by a set of elaborate bureaucratic requirements, which include not only recordkeeping and periodic review of all children placed in special education, but also detailed instructions regarding how children should be assessed, with what kinds of instruments the testing should be done, by whom, and in what language. ${ }^{8}$ The underlying assumption was that to the extent these mechanisms were faithfully employed, "general" justice would be served, and, therefore, all children would be afforded free, appropriate education.

Since Congress also knew that it was asking the same professionals who had excluded handicapped children in the past to now ensure their right to an appropriate education, it developed a second set of procedures for protecting that right. ${ }^{9}$ The most dramatic of these was the right to an impartial hearing, in a procedurally balanced forum, for parents dissatisfied with a school's classification or placement decision. ${ }^{10}$ Traditionally, courts and legislatures have used such due process hearings to guarantee accuracy in factfinding, participation in decisionmaking, and the perception of fairness to persons faced with the potential loss of liberty or property through acts of government. ${ }^{1}$ Ordinarily, they have concluded that the required degree of procedural safeguards should be determined by balancing the ability of various procedures to protect the private interest in question against the public costs of providing the procedures all in light of the importance of the interest at stake. ${ }^{12}$

In the case of special education hearings, Congress appears to have found that the interests of exceptional children so outweigh what Buss, Kuriloff, and

6. Board of Educ. v. Rowley, 458 U.S. 176, 189-90 (1982). Indeed, the language of the statute is circular:

The term 'free appropriate public education' means special education and related services which

(A) have been provided at public expense, under public supervision and direction, and without charge, (B) meet the standards of the State educational agency, (C) include an appropriate preschool, elementary, or secondary school education in the State involved, and (D) are provided in conformity with the individualized education program required under section 1414(a)(5) of this title.

20 U.S.C. § 1401(18) (1982); 34 C.F.R. § 300.4 (1984). In Rowley, Justice Rehnquist, writing for the majority, described this definition as tending "toward the cryptic rather than the comprehensive." 458 U.S. at 188 . Justice White, dissenting, argued that while the statutory language was not particularly clear, the legislative history provided a workable definition, and one more broadly drawn than the constricted view adopted by the Court. 458 U.S. at 213-16 (White, J., dissenting).

7. See 20 U.S.C. $\$ \$ 1401(19), 1412(4), 1414(a)(5)$ (1982). For a general discussion of congressional intent, see Neal \& Kirp, supra note 4.

8. Compare 20 U.S.C. $\S \$ 1412(5)$ with 34 C.F.R. $\S 300.340-.349, .530-.543$ (1984).

9. 20 U.S.C. $\$ 1415$ (1982).

10. Id.

11. Friendly, "Some Kind of Hearing," 123 U. PA. L. REv. 1267, 1270-75 (1975).

12. W. Buss, P. Kuriloff, \& T. Pavlak, Disciplinary Due Process: an Empirical Feasibility Study of Procedural Due Process, School Discipline, and Educational Environment 12-16 (N.I.E. Project No. 7-015, 1981). Buss, Easy Cases Make Bad Law: Academic Expulsion and the Uncertain Law of Procedural Due Process, 65 Iowa L. Rev. 1, 39-48 (1979). 
Pavlak term the out-of-pocket and disruptive costs of conducting hearings to protect those interests, ${ }^{13}$ as well as any potentially negative, long-range consequences affecting the relationship between professional educators, students, and parents, ${ }^{14}$ that such interests require adversary hearings closely imitating the judicial model. Parents must be notified in writing of any proposed alteration in their child's classification or placement, and the reasons for it. ${ }^{15}$ If they are dissatisfied with any part of the proposal, a timely hearing presided over by an impartial hearing examiner, is available upon their request. ${ }^{16} \mathrm{At}$ the hearing they have a right to legal counsel, to subpoena records, and to examine and cross-examine witnesses. ${ }^{17}$ The hearings may be open or closed to the public, at the parents' discretion, and a record of the proceedings must be kept. ${ }^{18}$ Finally, at the conclusion of the hearing, the parents have the right to receive a timely written decision, detailing the reasons for a given conclusion, ${ }^{19}$ and to appeal an adverse decision to the state department of education $^{20}$ and to state or federal court if necessary. ${ }^{21}$

Taken together, the safeguards mandated by Congress satisfy all the major elements of due process generally thought to be essential to a fair hearing. ${ }^{22}$ Despite the fact that such elaborate procedures represent a major new intrusion of the judicial model into the field of education, little research exists on the consequences of introducing them, ${ }^{23}$ and none examines the effectiveness of such procedures in resolving educational disputes justly. The purpose of this article is to describe research which attempts to do the latter. I first

13. W. Buss, P. Kuriloff \& T. Pavlak, supra note 12, at 1-16, 21-23.

14. These consequences have been discussed in detail in both judicial decisions and legal periodicals. See, e.g., Goss v. Lopez, 419 U.S. 565, 584-99 (1975) (Powell, J., dissenting) (expressing concern over the Court's intrusion on the functioning of state and local education systems); Mashaw, The Supreme Court's Due Process Calculus for Administrative Adjudication in Mathews v. Eldridge: Three Factors in Search of a Theory of Value, 44 U. CHI. L. REv. 28 (1976); Michelman, Formal and Associational Aims in Procedural Due Process, in Due Process 126 (J. Pennock \& T. Chapman eds. 1977); Kirp \& Jensen, What Does Due Process Do?, 73 Pub. InTerest 75 (1983); $f$. Tinker v. Des Moines Indep. Community School Dist., 393 U.S. 503, 515-26 (1969) (Black, J., dissenting) (expressing concern that Court's protection of students' free speech rights might lead to disruption of learning process in public schools). Perhaps the work that addresses the issue most directly as it relates to special education is Kirp, Buss \& Kuriloff, supra note 5.

15. 20 U.S.C. $\S 1415$ (b)(1)(C) (1982), 34 C.F.R. $\$ 300.504-.505$ (1984). For a further explanation of the requirements, see S. Goldberg, Special Education Law: A Guide for Parents, AdvoCATES AND EDUCATORS 19-46 (1982).

16. 20 U.S.C. $\S 1415(\mathrm{~b})(2)$ (1982); 34 C.F.R. $\$ 300.506-.507$ (1984).

17. 20 U.S.C. $\$ 1415$ (d) (1982); 34 C.F.R. $\$ 300.508$ (1984).

18. 20 U.S.C. $\S 1415$ (d) (1982); 34 C.F.R. § 300.508 (1984).

19. 20 U.S.C. $\$ 1415$ (d) (1982); 34 C.F.R. $\$ 300.508$ (1984).

20. 20 U.S.C. $\$ 1415$ (c) (1982); 34 C.F.R. $\$ 300.510$ (1984).

21. 20 U.S.C. $\$ 1415(\mathrm{e})$ (1982); 34 C.F.R. $\$ 300.511$ (1984).

22. See Friendly, supra note 11 , at 1279-95 (setting forth the elements of a fair hearing).

23. The major works are P. Hill \& D. Madey, Educational Policymaking Through the Civil Justice System (Rand Institute for Civil Justice, 1982); M. Budoff \& A. Orenstein, Due Process in Special Education: Legal and Human Perspectives, (HEW Bureau of Educ. for the Handicapped, Grant No. G007502322, 1979); P. Kuriloff, D. Kirp \& W. Buss, When Handicapped Children Go to Court: Assessing the Impact of the Legal Reform of Special Education in Pennsylvania (N.I.E. Project No. Neg. -003-0192, 1979). Most of it suffers from serious methodological weaknesses and extreme caution should be exercised in drawing conclusions from it. For a fuller discussion of these problems, see Neal \& Kirp, supra note 5. 
examine the assumptions underlying the imposition of due process hearings, showing they are used in the customary belief that they produce factually accurate, legally faithful decisions. In that respect, such outcomes represent an important part of what is understood as fair or just. I then argue that this ideal of justice cannot be assessed in special education hearings because professionals cannot agree on standards necessary to establish the accuracy of decisions. Instead, I suggest that a party's ability to influence administrative hearings in a desired direction by effectively using due process elements may be a reasonable substitute for accuracy. It is in the sense of this value-ability to influence outcome-that the term justice is used in this article.

Therefore, research on the capacity of special education hearings to produce equitable outcomes must examine the degree to which variations in the ways participants use the procedural elements of due process predict their ability to influence the outcome of the hearings in their favor. The finding of predictive relationships alone, however, will not be meaningful unless those relationships are examined in relation to the predictive power of other independent variables (such as the size of the district and the gender of the child). Such variables, although arguably irrelevant to the issues being decided in the hearing, might nevertheless affect outcome. After operationally defining the variables examined in the research, I describe how they were measured and the results of the inquiry. I conclude by arguing that on balance, the first four years of experience in Pennsylvania suggest that due process enables parents who use its elements effectively to influence the course of decisions, and in that sense to promote justice.

\section{Due Process, Participation, Accuracy, and Fairness}

Congress protects handicapped children's right to an appropriate education with a full panoply of procedural safeguards. Traditionally, the presence of such measures indicated that a vital private interest was at stake. Underlying the belief that the more important a private interest is, the more closely procedural safeguards must approximate those available in a trial, is the assumption that such procedures, beyond securing participation in decisionmaking, do in fact support accuracy in fact-finding and faimess. In the complex area of social welfare claims, which provide a rough analogy to the problem of determining an "appropriate" education, accuracy has been defined as "the correspondence of the substantive outcome of an adjudication with the true facts of the claimant's situation and with an appropriate application of relevant legal rules to those facts." 24 Fairness, in this framework, becomes "the degree to which the process of making claims determinations tends to produce accurate decisions." 25

24. Mashaw, The Management Side of Due Process: Some Theoretical and Litigation Notes on the Assurance of Accuracy, Faimess, and Timeliness in the Adjudication of Social Welfare Claims, 59 CoRNELL L. REv. 772, 774 (1974).

25. Id. at 775 . 
It takes little thought to realize that the link between procedures, as inputs, and accuracy and fairness, as products, is impossible to establish empirically. ${ }^{26}$ In real life there are simply no external criteria for confirming the "true facts" of a situation. If there is no way to establish what is "accurate," how can due process be evaluated? One answer is to assess how well decisions made in such hearings withstand appeal. ${ }^{27}$ Unfortunately, in special education hearings, the usefulness of the ability to withstand appeal as a measure of accuracy and fairness is suspect. If no objective, external standard exists in any kind of "truth"-determining hearing, it is especially obvious when determinations involve equally acceptable inferences from one set of "facts." And, while review may be an excellent test of a lower court's application of the law in traditional adjudications, decisions in special education at the local level emerge from a different legal framework than appeals at the state level. This appears to be the case in social security appeals. ${ }^{28} \mathrm{Kirp}$ and Jensen seem to imply that that is also true of the special education appeals process in Pennsylvania. ${ }^{29}$

Mashaw argues that absent external standards and comparability between local and state hearing officers, consistency in adjudication may be the nearest possible approximation of accuracy. ${ }^{30}$ But he goes on to cite a General Accounting Office study of social security appeals indicating little agreement among state agencies and between state agencies and federal decisionmakers. ${ }^{31}$ Given the potential variety and complexity of special education

26. Although not within the scope of the present study, it would be possible to measure fairness to the extent it is defined independently of outcome, by assessing participants' perceptions of the results of their hearings. Do they think the outcome was fair, whether or not they achieved their goals? But fairness may also be defined in terms of participants' feelings about their experience in the hearings. Instead of assuming that they have been treated in a "fundamentally fair" fashion because they have participated in a trial-like hearing, the researcher could ask them if the hearing process was fair. Of course, it is hard to imagine that the perception of fairness will not be somewhat enhanced simply by allowing people to participate in decisions which affect their lives. See Yudof, Legalization of Dispute Resolution, Distrust of Authority, and Organizational Theory: Implementing Due Process for Students in the Public Schools, 1981 WIS. L. REv. 891, 921 \& n.119. Indeed, there is some empirical evidence to support the proposition that, independent of outcome, people who have the opportunity to argue their cases in an impartial forum feel more fairly treated than those who do not. J. ThIBAUT \& L. Walker, Procedural Justice: A Psychological Analysis (1975). It is not difficult to imagine that they might also experience greater feelings of dignity and self-respect. This was one of the explicit premises underlying the Supreme Court's decision in Goss v. Lopez, 419 U.S. 565 (1975). Such values may be even more important in special education cases, where there is so much professional uncertainty about what constitutes an appropriate outcome. (A study of parental perceptions of the fairness of both the process and outcome of special education hearings in Pennsylvania is currently being conducted by S.S. Goldberg.).

27. Friendly, supra note 11, at 1294-95; Mashaw, supra note 24, at 785-87.

28. Mashaw, supra note 14, at 43-44. Mashaw points out that the Disability Insurance Manual, which is designed to promote consistency at the state level by objectifying the disability standard, is not used by administrative law judges in the hearings. Instead, they apply the statutory standard, together with regulatory medical listings-listings that Mashaw claims are usually irrelevant to cases reaching the hearing stage. He attributes these differences to the bureaucratic structure of decisionmaking at the state level, using relatively specific standards, as opposed to a local hearing process designed to foster individualized justice according to more general, statutory criteria. Id.

29. Kirp \& Jensen, supra note 14, at 81-84.

30. Mashaw, supra note 14 , at 43-45.

31. Id. at 44-45 \& n.56 (citing unpublished GAO study). 
claims, it is likely that a similar study in this area would produce similar results. Again, Kirp and Jensen's examination of special education appears to corroborate this hypothesis. ${ }^{32}$ To the extent this is correct, evaluating the linkage between procedures and outcome must depend on something other than the robustness of decisions under review.

While it might be possible to test the linkage in a laboratory experiment when the decision is confined to the simple binary choice between guilt and innocence, the problem increases in difficulty when it involves a real crime, and may become hopeless when the issue is what constitutes an "appropriate" education for a particular child. In the first place, there is abundant evidence to suggest that equally well-trained professional educators, working in good faith and under the best of circumstances in a nonadversary context, cannot agree on either the assessment or placement of handicapped children. ${ }^{33}$ These findings are consistent with those from other fields indicating, for example, that psychiatrists cannot agree on psychiatric diagnoses ${ }^{34}$ or clinical psychologists on emotional and behavioral disorders. ${ }^{35}$

In the second place, while it may be possible to assign such disagreements in psychiatric and psychological cases to a lack of current knowledge, the problem in educational decisionmaking is the assumption that there is one "best" or most "appropriate" placement. In fact, a whole range of programs exist that can help a particular child, and the degree to which they do depends on a mix of variables ranging from the child's current status and personality to the personality of the particular teacher and the nature of the other children in the class. Thus, choosing an appropriate program depends on the amount of knowledge about the child, what resources are available and the art of matching them effectively.

If the linkage between procedural safeguards and justice is to be tested for special education hearings, then an outcome criterion other than accuracy must be found. In the context of special education, the most straightforward alternative to "fairness as accuracy" may be the capacity of parents to influence the hearing officer's decision in their favor. Although not as grand a value as "Truth," the interest in being able to influence adminstrative decisionmaking, when it involves participants' vital concerns, has been recognized

32. Kirp \& Jensen, supra note 14.

33. See Flor, Service Provider Agreement and Special Education Reform, reprinted in 39 Dissertation AbStracts International. 6061 A (1979) (doctoral dissertation, Univ. of Pennsylvania, 1978); McDermott, Sources of Error in the Psychoeducational Diagnosis of Children, $19 \mathrm{~J}$. SCH. Psychology 31 (1981).

34. Freeman, A Reliability Study of Psychiatric Diagnosis in Childhood and Adolescence, 12 J. CHILD Psychology \& Psychiatry 43 (1971); Sandifer, Pettus \& Quade, A Study of Psychiatric Diagnosis, $139 \mathrm{~J}$. Nervous \& Mental Disease 350 (1964); Sandifer, Hordern, Timbury \& Green, Psychiatric Diagnosis, 114 Brit. J. Psychiatry 1 (1968); Spitzer \& Fleiss, A Reanalysis of the Reliability of Psychiatric Diagnosis, 125 Brit. J. Psychiatry 341 (1974).

35. Achenbach, \& Edelbrock, The Classification of Child Psychopathology: A Review and Analysis of Empirical Efforts, 85 Psychological Bull. 1275 (1978); Little \& Shneidman, Congruencies Among Interpretations of Psychological Tests and Anamnestic Data, in 73 Psychological Monographs: General and Applied, Whole No. 476 (1959); Zubin, Classification of the Behavior Disorders, 18 AnN. Rev. PsyCHOLOGY 373 (1967). 
in the legal literature. ${ }^{36}$ Using it, the linkage between procedures and outcome need not remain simply an irreducible article of democratic faith. While it brings us no nearer to a standard of accuracy (or truth), it does allow us to develop an important, measurable standard of justice by comparing what parents want with what hearing officers give them. ${ }^{37}$ It is then possible to correlate the relative ability of participants to use the procedural elements of due process effectively to achieve "justice," defined as what parents want from the system.

But participants do not use the elements of due process in a vacuum. It is certainly reasonable to wonder if other variables, irrelevant to the issues under consideration at a hearing, but nonetheless socially influential, may operate to skew the results, thereby undermining any conclusions which could be drawn from the due process variables themselves. Within this framework, it is possible to ask to what extent the success of participants in special education hearings is a function of their effective use of the elements of due process, and to what extent it is a function of other, less relevant characteristics such as the child's age and gender and the district's wealth and urbanization. Answers to such questions may prove the best possible gauge of how well justice, as used here, is served by special education hearings.

\section{III}

\section{The Research Questions}

To discover if the outcomes of the hearings-the degree to which parents are able to influence decisions in directions they desire-are related to the effective use of those procedural safeguards which traditionally have been held to support accuracy and fairness, the quality of use must be measured. How much contact did the parties have prior to going to a hearing? How well did parents prepare, independent of such efforts to work with the school? In the hearing, how well did the parties present their cases and support their arguments with witnesses and exhibits? How effectively did they crossexamine opposing witnesses? Did having a lawyer or other advocate materially improve their performance? In addition, the impartiality of hearing officers, while not under the control of either party, has been cited as the single most important element of due process. ${ }^{38}$ How impartial were they, and did evidence of bias correlate with the decisions they made? Were

36. See, e.g., Buss, supra note 12, at 17-21, 44-45, 94-95; Mashaw, supra note 14, at 37-39; Friendly, supra note 11, at 1270-75; Yudof, supra note 26, at 921 \& n.119. Contra Michelman, supra note 14 , at $148-53$.

37. Legal scholars such as Buss, see supra note 12, and Friendly, see supra note 11, would probably argue for an intermediate procedure that checks the relationship between this measure of justice and the presence (or absence) of each individual procedural element, and then between it and the amount of elements available, before attempting to relate it to the quality of the participants' use of the elements. The reality of special education hearings in Pennsylvania was the lack of variation in the number of elements the hearings contained. As a result, it was impossible to examine how combinations of different elements explained outcome in a statistical sense.

38. Friendly, supra note 11 , at $1279-80$. 
hearing officers who worked for districts more often favorable to schools than those who worked for intermediate units or colleges? Once all of these performance aspects in hearings are quantified, it is possible to see how they relate to outcome.

But as important as it is to know if effective use of the elements of due process could predict the outcome of hearings, it is equally important to know how two other sets of independent variables describing characteristics of the child and the school district related to it. If the process operated justly, some of these variables would be relevant to outcome, while others would not. Thus, except under very unusual circumstances, a child's age or sex should not influence the outcome of his or her case. Neither should the year of the hearing nor the child's prior involvement with special education. But the placement and services demanded by the parties might be relevant to a decision, not just for obvious reasons relating to the degree of their reasonableness or feasibility, but also as they became part of a knowing "bargaining strategy." Again, since Pennsylvania covers the excess cost of special education, ${ }^{39}$ the socioeconomic status of districts should not affect outcome, except perhaps in urban districts, where the impact of a variety of cross-cutting factors (desegregation, bureaucratic rigidity, a weak local tax base, and the like) may impede local efforts to provide quality services, and therefore make it difficult to counter parental claims. ${ }^{40}$ Only by examining the correlation of these variables to the outcomes of hearings independently, as well as in relation to the correlation of the elements of due process with those outcomes, will it be possible to gauge the efficacy of due process as a vehicle for the just resolution of disputes in special education.

\section{IV}

\section{Method}

\section{A. The Due Process Hearing Transcripts}

To answer these questions, we did a careful content analysis of the written transcripts of the first four years of hearings in Pennsylvania. Since those hearings were conducted under the rules set forth in Pennsylvania Association for Retarded Children v. Pennsylvania $(P A R C),{ }^{41}$ they were centralized and readily obtainable, once permission was obtained from the Deputy Attorney General in charge of the $P A R C$ case. The $P A R C$ due process regulations initially applied to retarded children, then were expanded to include all handicapped children, and finally, in 1976, were modified once again to include gifted

39. See PA. Stat. AnN. tit. 24, §§ 13-1373 to-1376 (Purdon Supp. 1984-85) (reimbursement by state to approved schools providing special education).

40. For a discussion of how such cross-cutting factors can affect a major school system such as Philadelphia's, see P. Kuriloff, S. Wedeman \& J. Day, The Impact of Chapter 2 Block Grants in Pennsylvania, Final Report to the E.H. White Company for the National Institute of EducaTION (1983) (available from the senior author).

41. 334 F. Supp. 1257 (E.D. Pa. 1971) (per curiam) (injunction and consent agreement), modified, 343 F. Supp. 279 (E.D. Pa. 1972). 
children. ${ }^{42}$

Using the first four years of hearings involved a trade-off. It limited our ability to generalize from the findings to hearings involving retarded children or those suspected of being retarded-children usually classified as either mentally retarded, learning disabled (LD), or brain injured (BI). It eliminated, however, the potentially serious confounding effects of hearings involving very different types of exceptional characteristics-physical disability, hearing impairment, severe retardation, and giftedness, for example. The choice nevertheless included a sample reflecting at least 60 percent of the total number of Pennsylvania cases (prior to 1983) and probably as many as 75 percent (if, as is likely, cases involving learning disability and brain injury followed a pattern similar to the present). ${ }^{43}$ Possibly this also reflects about 50 percent (and up to 70 percent) of cases nationwide, as reported by Smith, ${ }^{\mathbf{4 4}}$ given all other caveats applicable because of differences in state classification procedures. ${ }^{45}$

Parents requested 480 hearings during the period covered by the study. Of those, 172 actually resulted in hearings. We examined the full record of 168 such hearings. The transcripts were extremely varied. They ranged from a few pages, reflecting a hearing that lasted less than an hour, to over 200 pages, reflecting hearings lasting over two days. In certain hearings, parents appeared without representation and with little more than a feeling that their child was not retarded. In others, parents, sometimes represented by an attorney, secured several professional witnesses to support a sophisticated claim. The form of the hearings varied just as much as their substance. Some resembled court cases, with highly structured presentations followed by cross and redirect examinations. Others seemed little more than parallel monologues interrupted occasionally by the hearing officers' plaintive attempts to clarify and relate them.

\section{B. The Due Process Coding Instrument}

After the project administrator removed all identifying material from transcripts which parents elected to close to the public, all the transcripts were coded, using the Due Process Coding Instrument ${ }^{46}$ and the Due Process Coding

42. 22 Pa. Admin. Code ch. 13 (1984) (the $P A R C$ due process regulations as amended); $22 \mathrm{PA}_{\mathrm{A}}$ Admin. Code $\$ \S 13.21-.23$ (1978) (expression to all gifted and/or talented children). Catherine D. Pittenger, Civil No. 74-2435 (E.D. Pa.June 27, 1975) (expansion of state due process regulations to all handicapped children).

43. See O'Connor, Information Concerning Special Education Hearings (Memorandum to the Pennsylvania State Attorney Panel for Special Education, Technical Assistance Group for the Right to Education, 1983).

44. Smith, Status of Due Process Hearings, 48 Exceptional Children 232, 234 (1981).

45. As of 1981, there had been 555 hearings in Pennsylvania, 314 ( 57 percent) involving retarded children and 108 (19 percent) involving learning disabled (LD) or brain injured (BI) children. Id. The national figures, based on Smith's work, appear closer to 35 percent and 20 percent, respectively. Id.

46. Kuriloff \& George, Due Process Coding Instrument, in P. Kuriloff, D. KIRP \& W. Buss, supra note 23 , app. IV. 
Manual. ${ }^{47}$ The instrument contained 207 items describing the child, the prehearing behavior of the parents (as inferred from their hearing behavior), the behavior of parents at the hearing, behavior of the school personnel, and the behavior of the hearing officer. Of these, some covered factual variables, such as the child's age, the number of witnesses called by the parents and the school, and the hearing officer's professional affiliation. Others described such things as the central issues of the case and the central arguments used by the parents and the school. Besides explicitly describing aspects of parents' and school personnel's behavior that indicated how effectively they used the elements of due process, the items also covered a number of variables we felt might mediate the outcome of the hearings, such as the size of the district and the number of years the child spent in special education prior to the hearing. A final set of items rated various aspects of the hearing officers' behavior and whether their decisions favored the parents or the schools. This measure, the dependent variable, described the overall outcome of the case in relation to what the parents demanded on a five-point Likert scale ranging from: $1=$ Complete Loss, where parents do not receive the placement they request or any desired services arguably relevant to their case, to $\mathbf{5}=$ Complete Win, where parents win desired placement and the majority of desired services. Appendix A describes the thirty variables used for the present analysis.

\section{Coding and Reliability}

An initial group of three coders, blind to the purposes of the study, were trained on a typical transcript. After roughly $\mathbf{5 0}$ hours of work together, they independently coded three randomly selected transcripts. The few discrepancies that emerged were again discussed until consensus was reached on the coding of all items. After this, six new transcripts were drawn at random and again coded independently by each coder. At this point the coders agreed, on the average, about 98 percent of the time on factual items, such as the child's age, and 93 percent of the time on the scaled items, such as rating the quality of the parents' presentation. Two new teams of three coders each were then added and trained in a similar manner. Coding the same six transcripts, there were no significant differences when the internal agreement of each team's members, agreement among the teams, and agreement among all the individuals, were compared. The same procedures were used to train coders to rate the hearing officers' decisions. Again, agreement was quite high, averaging 97 percent for factual items and 90 percent for scaled items such as the degree of hearing officer partiality.

Having established an acceptable degree of reliability, the 168 transcripts were divided among the nine transcript coders, and the hearing officer recommendations among the three recommendation coders. Each coder's work was

47. Kuriloff \& George, Due Process Coding Manual, in P. KuRILofF, D. KirP \& W. Buss, supra note 23, app. V. 
checked thoroughly by a research supervisor and any discrepancies were reconciled through discussion eventually reaching a consensus.

\section{V}

RESULTS

\section{A. Who Won?}

It does not make sense to try to predict the outcome of a due process hearing using either procedural elements or potential mediating variables, unless parents (or schools) in fact "won" some substantial portion of the cases. If parents never won, or won only an insignificant percentage of them, no credible claim may be made for the effectiveness or fairness of the hearings.

When hearing officers' decisions were compared to what parents demanded, we found that parents won, in whole or in part, in 59 out of the 168 cases, losing in 104 (in the remaining 5 hearings, the hearing officer's decision was so different from what the parent or school wanted, that it could not be counted). In other words, parents achieved some form of victory in 35 percent of the hearings. This parallels roughly the winning percentage that was found in Massachusetts and in a nationwide survey of forty-two states, certainly suggesting that parents are able to achieve some satisfaction in a significant portion of the hearings. ${ }^{48}$

When the cases are segregated into those classifying children and those involving disputes over the content and quality of programs, the picture becomes clearer. Of 114 cases in which classification issues were central, parents won 33 , or 28 percent. Of the 87 cases involving content or quality, parents won 43 , or 49 percent (33 cases involved both kinds of issues so the sum does equal 168). Content or quality questions were much more likely to arise in more seriously retarded children, many of whom had a long and often rocky history with public schools prior to the $P A R C$ case. ${ }^{49}$ Below, I will address the question whether this result can be explained by the fact that hearing officers tended to right past wrongs against seriously retarded chil-

48. For the Massachusetts analysis, see M. Budoff \& A. Orenstein, supra note 23; for the nationwide results, see Smith, supra note 44 . Much worse results for parents have been reported by Kirp and Jensen, supra note 14 . The problem seems to lie in what criteria are used to determine whether a party has won. While Smith did not indicate the criteria used in his survey, Kuriloff, Kirp, and Buss described parents as partial winners whenever a decision granted them any of their substantial demands. P. Kuriloff, D. Kirp \& W. Buss, supra note 23, at 158. Budoff and Orenstein, using an adaptation of the methodology developed by Kuriloff, Kirp and Buss, employed similar criteria with similar results. A careful examination of the source of Kirp and Jensen's 4 percent win rate shows that it includes only parents whose claims were fully successful. O'Connor, Special Education Due Process Hearings in Pennsylvania 6 (Paper presented at the international convention of the Council for Exceptional Children) (April 16, 1981). Read more liberally, O'Connor's data suggest that parents won between 31 and 42 percent of the cases, a result which would be consistent with the other studies cited here.

49. Pennsylvania Ass'n for Retarded Children v. Pennsylvania, 334 F. Supp. 1257 (E.D. Pa. 1971) (per curiam) (injunction and consent agreement), modified, 343 F. Supp. 279 (E.D. Pa. 1972); see supra text accompanying notes 41-42. 
dren and show less concern about the unproven dangers of EMR (educably mentally retarded) versus LD or BI placement (around which most classification battles raged), or by the fact that parents of more seriously handicapped children simply did a better job pleading their case in the hearings.

\section{B. The Relationships Among Selected Child Variables, Elements of Parental Behavior, and the Outcome of Hearings}

Table I presents the correlations ${ }^{50}$ among variables describing the child, key aspects of the parents' hearing performance, and the hearing officer's decision. Aside from their decision to open or close the hearing to the public, it reveals a consistent set of moderate to strong, significant relationships. Of the twelve variables, nine were associated with outcome.

While neither the age nor the sex of the child was related to outcome, previous special education experience $(\mathrm{r}=.34)$, current placement $(\mathrm{r}=.31)$, and the restrictiveness of placement $(r=.19)$ were. Parents of children who had spent time in special education, who had more serious handicaps, and whose placements were more restrictive, tended to win their hearings more often than parents of children who had never been in special education, who were less serioiusly handicapped, and who had been placed in less restrictive environments.

But winning was not merely a matter of having a more seriously handicapped child; a finding of that alone would tend to cast doubt on the value of using the procedures well. Parents who presented their cases better also won more often than those who did not. With the exception of the decision to have a lawyer and to close hearings to the public, there were significant, moderate correlations between outcome and the number of exhibits parents presented $(r=.24)$, the number of witnesses they called $(r=.42)$, their preparation for the hearing-not including contact with the school- $(\mathrm{r}=.30)$, the degree to which their demands taxed the school's resources $(r=.32)$, the effectiveness of their questioning of school witnesses $(r=.30)$, and the overall quality of their presentation $(r=.39)$. Furthermore, these variables correlated significantly (and moderately to strongly) with each other. The presence of a lawyer representing parents correlated .45 with the number of exhibits they used and the number of witnesses they called, .76 with the quality of their questioning, and .65 with the overall quality of their presentation. There were, in addition, equally strong interrelationships among these variables. The number of exhibits parents entered correlated .52 with the number of witnesses they called, .55 with their prior preparation, .45 with the quality of their questioning, and .59 with the overall quality of their presentation. The

50. A correlation expresses mathematically the strength of the relationship between two variables. Correlations range from +1 to -1 . A complete lack of relationship is expressed as " $r=0$, , a perfect relationship as " $\mathrm{r}=+1$ " or " $\mathrm{r}=-1$ " (the negative sign indicating an inverse relationship). Multiple correlations express the strength of the relationship among several independent variables and a "criterion" variable in such a fashion that it is possible to see the "unique" contribution of each independent variable to the overall correlation ("prediction" or "explanation"). 


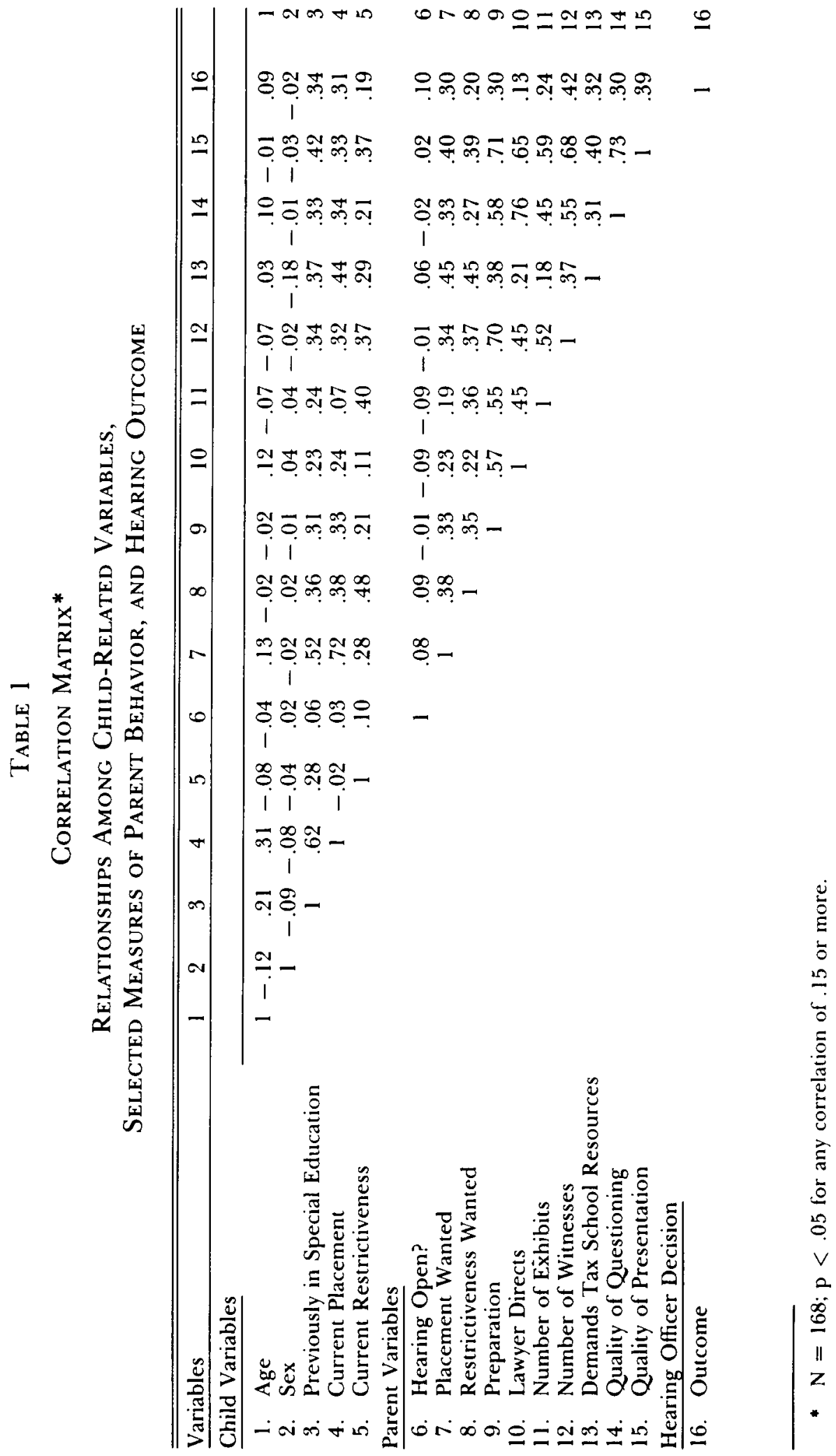


number of witnesses correlated .70 with prior preparation, .55 with the quality of their questioning, and .68 with the overall quality of their presentation. The quality of their questioning correlated .73 with their overall effectiveness.

These dimensions of presentation were not as strongly, though still significantly, related to the degree to which parental demands taxed schools' resources. Such demands correlated .21 with representation by counsel, .18 with the number of exhibits, .37 with the number of witnesses, .31 with the quality of questioning, and .40 with the overall quality of presentation. It seems likely that making a larger number of costly demands was often part of parents' strategy for winning a hearing.

To bring the matter full circle, however, all the dimensions of performance we measured, with only one exception, were also moderately and significantly related to the child's current placement: $r=.24$ with having a lawyer direct the case; $r=.32$ with the number of witnesses; $r=.33$ with prior preparation; $r=.44$ with taxing the school's resources; $r=.34$ with effectiveness of questioning; and $r=.33$ with overall quality of presentation. Only the number of exhibits was unrelated to the current placement's restrictiveness. Similarly, with only one exception (having a lawyer direct the case), the current degree of restrictiveness was related to all the elements of performance $(r=.40$ with exhibits, $r=.37$ with witnesses, $r=.21$ with prior preparation, $r=.29$ with taxing the school, $r=.21$ with questioning, and $r=.37$ with overall quality). In other words, the more severe the child's disability, the better the parents argued the case.

These findings show that while the results of the hearings were not related to irrelevant variables such as the age and gender of the child, they were associated with other intervening variables. Rather than skewing the results, however, those variables help to explain them further. Of course, it seems logical that the degree to which parental demands taxed school resources was also related to the seriousness of the child's handicap. Yet beyond that obvious relationship, the correlation of all key performance variables with severity of handicap, together with the other relatively strong correlations among performance variables, including making demands on the school, suggest that parents of more seriously retarded children tended to be more effective in the hearings than parents of less retarded children, perhaps because they had had more experience battling the school.

\section{The Relationships of Selected Elements of the School's Hearing Performance and Outcome}

A different picture emerges when the relationship between outcome and key aspects of the school's performance in hearings is examined. In terms of intervening variables, parents from more urbanized districts, and districts within intermediate units (I.U. $)^{51}$ with larger populations, tended to

51. In Pennsylvania, the state's 501 school districts are organized into 29 intermediate units which provide ancillary services, including much special education, that districts would find difficult or prohibitively expensive to supply on their own. 


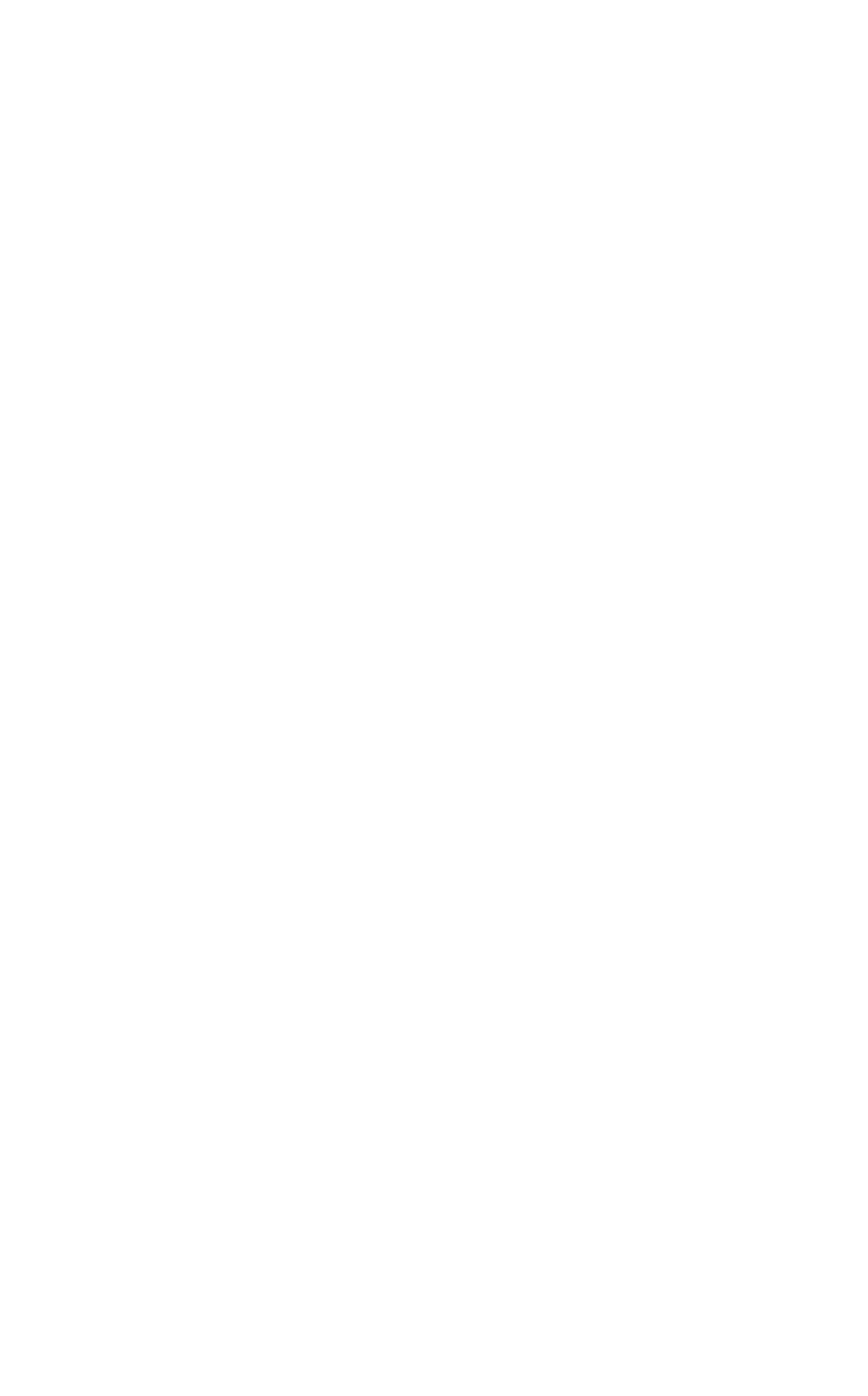


win their cases somewhat more frequently then those from less urbanized districts or intermediate units with smaller populations $(r=-.27$ and $r=.20$, respectively). ${ }^{52}$ Neither the educational level nor the median family income level of a district's I.U. were associated with outcome. ${ }^{53}$

In terms of school performance variables, the normality of placement proposed by the school was related significantly to parental success $(r=.31)$, while the restrictiveness of the proposed placement was not. ${ }^{54}$ Neither was the school's prehearing involvment with the parents, the number of witnesses or exhibits the school presented, nor its having a lawyer present its case. What did matter was the degree to which the school met such requirements of the law as conducting a broad evaluation, presenting a flexible prescription, and proposing an individualized program that followed from the evaluation and prescription $(r=-.25)$ and the overall quality of the school's presentation $(r=-.39)$. In other words, parents tended to lose their cases when schools asked for more mildly handicapped placement categories, when schools followed the procedural aspects of the law, and when, in the judgment of the coders, schools presented their cases well. Parents tended to win when schools did not do those things. Furthermore, as the data in Table 1 reveal, for parents the logically related elements of the adversary process held together in a coherent pattern. But the data in Table 2 show that for schools, those elements were much less strongly related.

The presence of a lawyer who actively managed the case for the school did not correlate significantly with the number of witnesses the school called, the number of exhibits it presented, or with the school's compliance. Furthermore, it was only weakly related to the overall quality of the school's presentation $(r=.15)$. The number of exhibits and witnesses the school offered were modestly related $(\mathrm{r}=.18)$ and both of these, in turn, correlated with the overall quality of the school's presentation $(\mathrm{r}=.31$ and $\mathrm{r}=.25$, respectively). Finally, a school's compliance was significantly and moderately related to its involvement with parents prior to the hearing $(r=.27)$ and strongly related to

52. The direction of the sign in these two correlations is a function of the way urbanization and size were coded. The text presents the proper interpretation of the relationships.

53. Socioeconomic status (SES) data (a measure combining mean income and mean educational attainment of persons over 25 within the 1.U.'s) on I.U.'s were used because district census data were not available. Since the SES of districts within I.U.'s varies greatly, these correlations must be viewed as providing, at best, approximations of the strength of any real relationships among SES variables and the outcome of hearings. For that reason, it did not seem wise to use them in larger correlational or multiple regression analyses. The only demographic variable employed for those was a measure of district urbanization.

54. The terms "normality" and "restrictiveness" are not opposites. Normality of a placement, as used here, refers to the degree to which the IQ's or social behavior of children placed in the class deviate from what is considered "normal" by state standards. (For the state's definition of exceptional children, see Pa. Star. Ann. tit. 24, \$ 1371 (Purdon Supp 1984-85).). Such a placement could be in any of a variety of more or less "restrictive" locations. The restrictiveness of a child's placement refers to how close it is to the usual setting in which an ordinary child of ordinary intelligence would be taught. Thus, a class in a regular school would be defined as less restrictive than a class in a special school, and a class in a special school would in turn be considered less restrictive than one in a state hospital. For the rankings of normality and restrictiveness used in the present study, see Appendix A, infra. 
the overall quality of its presentation $(r=.54)$. Yet, most of these elements of presentation were no more strongly related to each other than to the school district's size, the child's current placement, or the placement the district was requesting.

There were significant though modest positive correlations between the urbanization of the school district and the number of exhibits $(r=.25)$ and witnesses $(r=.20)$ it employed, as well as the degree of its compliance with the law $(r=.27)$. Urbanization was also correlated with the overall quality of the school's presentation $(r=.21)$. In fact, with the exception of their tendency to be less often represented by counsel $(r=-.27)$, less urban school districts behaved in ways that were arguably more effective in hearings than did more urban districts. ${ }^{55}$ They also seemed to comply more with the law $(r=.27)$. Furthermore, urbanization was negatively related to the school's desired placement $(r=-.28)$, but positively, if weakly, related to the restrictiveness of that placement $(r=.16)$. More urban school districts tended to ask for lower classifications than less urban districts, and for placements in less restrictive environments. Perhaps this indicates that less urban districts tended to heed the principle of normalization, but once they classified a child as seriously handicapped, their choice of facilities was narrower. These districts simply lacked the types of differential services commanded by more urban districts. Whatever the reason, the fact that less urban districts acted more effectively and complied more fully with the principle of normalization probably explains the fact that they tended to win more often than more urban districts $(r=-.27)$. Moreover, parents tended to win more often in more urban districts while losing more often in less urban ones.

The child's current placement correlated significantly but weakly with the school's active use of a lawyer $(r=.16)$ and negatively with the number of exhibits it presented $(r=-.15)$, its compliance $(r=-.21)$, and the overall quality of its presentation $(\mathrm{r}=-.27)$. Taken together, these findings suggest that schools had a slight tendency not to argue their cases as well as the seriousness of the child's handicap increased. They also tended, to argue their cases less well as the seriousness of the placement they requested increased. The placement the school requested was moderately negatively related to its number of exhibits $(r=-.31)$, the degree of its compliance $(r=-.33)$, the amount of its involvement with parents prior to the hearing $(r=-.20)$, and the overall quality of its presentation $(r-.30)$; it was unrelated, however, to the school's having a lawyer manage its case. This suggests, at least in the early years after $P A R C$, that schools did not fully understand the necessity of careful preparation when they were asking for a less normalized placement or appreciate the burden of defending decisions regarding children already in a placement for the more seriously handicapped. It is interesting to note that a school's reported contact with parents tended to decrease as the severity of

55. See supra note 52 . 
the placement it requested increased. Certainly, this could have been a factor contributing to the need for a hearing in the first place.

\section{The Relationship Between Selected Hearing Officer Variables and Outcome}

An impartial hearing officer has long been the sine qua non of procedural fairness. Yet as Judge Friendly has noted, while strong disagreement arises over how much prior participation constitutes bias, "there is wisdom in recognizing that the further a tribunal is removed from the agency and thus from any suspicion of bias, the less may be the need for other procedural safeguards . . . "56 Table 3 presents data which reflect the relationships, both to each other and to hearing outcome, of four measures of hearing officer characteristics and behavior, including bias. ${ }^{57}$

The table reveals significant, though very modest, relationships between hearing officer affiliation and parents' winning $(\mathrm{r}=.15)$, and between hearing officer partiality toward parents and parents' winning $(r=.15)$. It also reveals an equally weak, though significant, relationship between the activity level of the hearing officer during the hearing and outcome $(r=-.17)$. This means that parents fared better when the hearing officer was less directly associated with local schools, less active during the hearing, and more biased in favor of the parents. Parents did worse if the primary work affiliation of the hearing officer was with the local schools, if the hearing officer was more active during the hearing, and if he or she was more biased in favor of the school.

TABLE 3

\section{Correlation Matrix*}

The Relationships Among Selected Hearing Officer Variables and HEARING OUTCOME

\begin{tabular}{|c|c|c|c|c|c|}
\hline & 1 & 2 & 3 & 4 & 5 \\
\hline 1. H. O. Affiliation & 1 & .01 & .03 & .18 & .15 \\
\hline 2. H. O. Does Most Questioning & & 1 & .27 & -.08 & -.17 \\
\hline 3. H. O. Complies With Law & & & 1 & .17 & -.00 \\
\hline 4. H. O. is Partial & & & & 1 & .15 \\
\hline 5. Outcome & & & & & 1 \\
\hline
\end{tabular}

56. Friendly, supra note 11 , at 1279.

57. Following standard criteria specified in Kuriloff \& George, supra note 46, bias was judged by rating the hearing officers' total verbal behavior (as it appeared in the transcripts) for partiality to either parents or school districts. In particular, judges rated whether hearing officers favored one side or the other by refusing to admit arguably relevant testimony, by calling testimony or evidence into question after admitting it, by clarifying some responses or statements as opposed to others, by discrediting some witnesses, or by showing differential anger or impatience. The rating scale, logether with the actual items employed, may be found in Appendix A, infra. 


\section{Factor Analysis}

Factor analysis ${ }^{58}$ of the thirty independent variables helps clarify the underlying meanings suggested by the preceding analysis of individual groups of correlations. The analysis resulted in the identification of four coherent factors, each meeting the criteria of (1) accounting for at least 5 percent of the overall variation and (2) having an Eigen Value over 1.5. Only two of the factors, however, had more than two loadings over .40, and even those were

TABLE 4

Oblique Factor Structure*

\begin{tabular}{|c|c|c|c|}
\hline \multicolumn{2}{|c|}{ Factor } & Item & \multirow{2}{*}{$\begin{array}{c}\text { Factor Loading } \\
.88\end{array}$} \\
\hline I. & Quality of Parents' & Lawyer Present for Parents & \\
\hline & Presentation & Effectiveness of Parents' & .84 \\
\hline & & $\begin{array}{l}\text { Hearing Officer Does Most of } \\
\text { the Questioning }\end{array}$ & -.76 \\
\hline & & Quality of Parents' Presentation & .72 \\
\hline & & Lawyer Presents School's Case & .66 \\
\hline & & Parents' Preparation & .61 \\
\hline & & Number of Parental Exhibits & .50 \\
\hline & & Number of Parental Witnesses & .49 \\
\hline \multirow[t]{2}{*}{ II. } & Quality of School's & Quality of School's Presentation & .75 \\
\hline & Presentation & $\begin{array}{l}\text { Degree of School's Compliance } \\
\text { with Law }\end{array}$ & .73 \\
\hline \multirow[t]{2}{*}{ III. } & $\begin{array}{l}\text { Normalization of } \\
\text { Current Placement }\end{array}$ & $\begin{array}{l}\text { Restrictiveness of Current } \\
\text { Placement }\end{array}$ & .63 \\
\hline & & $\begin{array}{l}\text { Restrictiveness of Placement } \\
\text { School Wants }\end{array}$ & .60 \\
\hline \multirow[t]{4}{*}{ IV. } & Child's Current & Child's Current Placement & .96 \\
\hline & Classification & Placement School Wants & .80 \\
\hline & & Placement Parents Want & .78 \\
\hline & & $\begin{array}{l}\text { Child Previously in Special } \\
\text { Education }\end{array}$ & .47 \\
\hline
\end{tabular}

* After rotation with Kaiser Normalizations.

58. A correlation expresses the relationship between two variables. When many variables are being used to understand a phenomenon, a statistical technique called factor analysis may be employed. Factor analytic techniques enable the researcher to determine whether any underlying patterns of relationships exist among a complex array of correlation coefficients. Such patterns, or factors, are then examined to see if they may be taken as "source variables" accounting for the observed interrelationships in the data. Factor analysis is principally used to explore variables in order to discover patterns and to confirm theoretically derived hypotheses about the structure of phenomena. In the present study, I used it to validate inferences drawn from the welter of intercorrelations discussed in the preceding sections of this paper. For a clear, useful description of the various types of factor analyses, see Kim, Factor Analysis, in Statistical. Package for the Social SCIEnCES 468 (2d ed. 1975). 
quite difficult to interpret. When an oblique rotational method (which allows factors to be correlated) was used to arrive at a terminal solution, this problem was overcome, yielding four clear, theoretically meaningful factors, each of which complemented the other findings of this research. ${ }^{59}$

As can be seen in Table 4, Factor 1, Quality of Parents' Presentation, loaded heavily on the active participation of a lawyer $(.88)$, the effectiveness of the questioning (.84), and the overall quality of the parents' presentation (.72). All of the other elements of presentation appear in the factor with decreasing loadings. The only item to load negatively on this factor, whether the hearing officer did most of the questioning $(-.76)$, also appears to fit, as it suggests that hearing officers tend to take over when parents are not making a strong case for themselves. Factor 2, Quality of School's Presentation, only loaded heavily on the overall quality of the school's presentation (.75) and the school's compliance with the law (.73). Factor 3, Normalization of the Current Placement, loaded most heavily on the restrictiveness of the child's current placement (.63) and the restrictiveness of the placement the school wanted (.60). Factor 4, Child's Current Classification, loaded very heavily on the child's current placement $(.96)$, the placement the school wanted $(.80)$, and the placement the parents wanted (.78); it loaded less heavily on the child's having been in special education (.47).

Together, the factors strongly support the reality of the patterns inferred from the individual correlations among the variables: effective hearing behavior for parents required use of the full panoply of adversary skills, while for schools it seems to involve a combination of compliance with evaluation requirements and overall skill in presentation. Such skill depended more on organization and clarity, and less on direct combativeness. The restrictiveness of the child's current placement and agreement between school and parents over his or her classification appear to represent intervening variables that affected the hearing process.

\section{VII}

\section{Predicting Outcome: Multiple Regression Analysis}

Discussion of the zero-order correlations of the independent variables with outcome, along with discussion of the interrelationships among the predictor variables, raises the question of how these variables might combine to account for outcome. Table 5 presents a summary of the results of a regression analysis designed to answer that question. Only the three variables that made a significant $(\mathrm{p}<.05)$ contribution to the multiple $\mathrm{R}$ are included. The variable most strongly correlated with outcome was the number of wit-

59. This result makes sense given Kim's argument that while "orthogonal factors are mathematically simpler to handle. . oblique factors are empirically more realistic." Kim, supra note 55, at 474. This seems especially true given the inherent intercorrelation of factors examined in this study. 
TABLE 5

Multiple Regression Summary: Predicting Hearing Outcome*

\begin{tabular}{llrccc}
\hline \hline Step & \multicolumn{1}{c}{ Variable } & Simple r & Multiple R & Multiple R & $\mathbf{R}^{2}$ Change \\
\hline 1. & No. of Parental Witnesses & .42 & .42 & .18 & .18 \\
2. & Quality School's Presentation & -.39 & .55 & .31 & .13 \\
3. & Child Previously in Special Education & .34 & .57 & .33 & .02 \\
\hline
\end{tabular}

* $\mathrm{N}=168$.

nesses employed by the parents. Alone, it accounted for 18 percent of the variation. After it was entered, two more variables reliably explained an additional 15 percent of the variation in outcome. The first of these, overall quality of the school's presentation, accounted for 13 percent. Once it was entered, the second, whether the child had previously been in special education, added another 2 percent. Together, the three variables explained a considerable 34 percent of the variation in outcome.

\section{VIII}

\section{Discussion}

When viewed together, the zero-order correlations, the factor analysis, and the multiple regression all suggest that the way participants used the elements of due process was associated with the results they achieved. Parents who performed well in one aspect of the hearings tended to perform well in other aspects, and such performance was in turn related to winning their cases. The fact that being represented by a lawyer did not correlate significantly with outcome, but did relate to the other elements of effective presentation, does not detract from this conclusion. Instead, it suggests that while lawyers could help with the process, they were not essential to it.

The results of the multiple regression analysis capture this process well. The number of witnesses parents called was one of the aspects of their performance that should have been related to outcome if the hearings were working in a way that enabled people who used the procedures effectively to influence the decisions in their favor. Indeed, since determining the number of witnesses simply involved counting those appearing in the transcripts, it may have been our most reliable proxy for the quality of parent performance. Recall that the number of witnesses correlated very strongly with the number of exhibits parents entered, the quality of their questioning, the presence of an active lawyer, and the overall quality of their presentation. ${ }^{60}$

The fact that the overall quality of the school's presentation explained the most additional variation in outcome, once the number of parental witnesses was entered into the equation, increases our faith in the integrity of the hearing process. It meant that parents' success was not only related to their own relative effectiveness but also to the school's relative ineffectiveness:

60. See supra Table 1. 
good performance by parents combined with poor school performance to predict a decision favorable to parents.

The third variable in the regression appears to accord with this view as well. Parents of children with previous experience in special education may have won more often because hearing officers held schools to a higher standard in such cases than in cases involving children who were for the first time being considered for special education. The data also shows, however, that parents of children already in special education developed considerable expertise in advocacy. Recall that previous assignment to special education correlated moderately with the number of parent exhibits and witnesses, the quality of questioning, and the overall quality of their presentation. ${ }^{61}$

Taken together, these findings suggest that, for the first four years in Pennsylvania at least, the expected and logical relationship between the elements of effective performance for parents and outcome pertains. For schools, the expected elements of effective performance were also related, but not as strongly. These findings suggest that what it took to win was somewhat different for the two parties.

Perhaps the style of the schools' presentations reflected the fact that hearing officers were holding them to the letter of the new law because of the schools' legal duty to "go forward"-to present the program they viewed as "appropriate" to meet the needs of the child, as well as their reasons for it, prior to the parents' presentation. This may have made the other, more conventional elements of the adversary process less important for schools. Apparently, schools did not have to rebut parents' arguments through crossexamination, or develop overwhelming arguments of their own through the orderly presentation of witnesses and exhibits. What they had to do, it seems, was to convince the hearing officer that they were acting in good faith and within the framework of the law. It was sufficient to demonstrate that they followed the necessary evaluation and prescription procedures, and that in classification and programming they attempted to provide the most normal setting possible.

In contrast, hearing officers' concern for parents appears to be twofold. First, they appear to pay close attention to what the parents demanded and how persuasively they argued for it. Second, they seemed to have assessed carefully how effectively the parents argued against what the school proposed. The results of these different attitudes towards parents and schools seem to reflect a certain tension within the law itself. A tension that at once invites parents to attack the school's position while simultaneously implying that schools, represented by professionals, should avoid an adversary stance in favor of serving the best interest of the child.

61. Id. 
IX

\section{More Questions to Answer}

Due process in special education has worked in practice as a quasi-judicial, equalizing forum, just as its advocates envisioned. ${ }^{62}$ Parents who make relatively effective use of the available procedural safeguards are more likely to influence the decision than parents who make relatively less effective use of them. Care must be taken, however, to make neither too much nor too little of this central finding.

This study does not examine whether the results parents achieve are less a function of their inherent skills than an effect of their socioeconomic status. In a subsample of forty-two parents, drawn from the 168 cases reviewed here, we found no relationship between the results parents received and their occupational status. ${ }^{63}$ And in a larger, though less systematic sample, Kirst and Bertken actually found that poor parents in California, though seriously underrepresented in the sample, won more frequently than their wealthier counterparts. ${ }^{64}$ Further research is needed to discover what lies behind these findings. Are they simply artifacts of the pre-EAHCA era, when the handicapped children of poor parents received such poor educational services that hearing officers, during the first years of the reform, had no choice but to differentially reward them? Or are poor parents asking for different, and more easily granted programs and services than rich parents? Yet, an even more pressing question arises if Neal and Kirp are correct in suggesting that the hearings have been used largely by middle class people. ${ }^{65}$ Then the issue becomes one of equal access, and the question whether the hearings are effective vehicles for allowing parents to influence educational decisions must be understood within the context of the question of "which parents?"

Again, the present study looks only at hearings involving children thought to be retarded by one party to the dispute. Do hearings work the same way for other kinds of handicapped children? The research of Budoff and Orenstein, ${ }^{66}$ who, using an instrument adapted from our own work, ${ }^{67}$ found a similar factor structure for Massachusetts hearings primarily involving children classified as learning disabled and emotionally disturbed, suggests that they may. Unfortunately, Budoff and Orenstein did not attempt to develop a predictive model from their findings. Such a model would make a considerable contribution when compared to the present findings. ${ }^{68}$

62. Gilhool, The Uses of Litigation: The Right of Retarded Children To a Free Public Education, 50 Peabody J. Enuc. 120 (1973); P. Kuriloff, D. Kirp \& W. Buss, supra note 23, at 169-81; Neal \& Kirp, supra note 4.

63. Kuriloff \& Hoffman, Parents React to Due Process Hearings (unpublished raw data, 1976) (available from the senior author).

64. Kirst \& Bertken, Due Process Hearings in Special Education: Some Early Findings from Califormia in Special Education Policies: Theory, History, Implementation, and Finance 136 (1983).

65. Neal \& Kirp, supra note 4 , at 78.

66. M. Budoff \& A. Orenstein, supra note 23.

67. Kuriloff \& George, supra note 46.

68. M. Budoff \& A. Orenstein, supra note 23. 
Finally, this study does not look at the question of the satisfaction of parents who have gone through hearings. Neal and Kirp's review suggests that parents often feel blamed by school districts for being either bad parents or troublemakers, while school personnel often feel that the mere request for a hearing impugns their professional judgment and dedication to promoting the welfare of children. ${ }^{69}$ Are the outcomes of hearings worth such emotional costs?

Perhaps they are, for those parents who feel that they have at last "had their day in court," but perhaps not, for those who, having gone through the battle, find that despite the hearing nothing substantial has changed for their children. Even here, however, we are talking about only a tiny fraction of those parents eligible for hearings. Assuming that the orders of the hearing officers have been uniformly implemented in every case, the programs of some 742 children in the forty-two states surveyed by Smith have been altered as a result of hearings. ${ }^{70}$ Yet of course, the simple availability of due process has a subtler "ripple effect" which is difficult to measure. We simply do not know to what extent districts, eager to avoid future reversals, or wishing simply to avoid hearings altogether, have become more responsive to parental concerns-or at least, to what they believe a hearing officer might require. One study has found that school psychologists reported much change in that direction. ${ }^{71}$ The present research indicates that due process hearings in special education may indeed serve the value of "equalization" envisioned by Professor Mashaw, ${ }^{72}$ giving parents the tools to alter a balance that has too often been tipped against them in the past. Whether (as the authors of both $P A R C$ and the EAHCA had hoped) the hearings extend beyond that form of individual justice to become a major instrument for institutional reform remains perhaps the central research question for those interested in evaluating the long-term consequences of imposing due process on American education.

69. Neal \& Kirp, supra note 4 , at 79.

70. Smith, supra note 44 , at 235 .

71. P. Kuriloff, D. KirP \& W. Buss, supra note 23 , at 56-60.

72. Mashaw, supra 14, at 52-54. 
Appendix A

Description of Variables Used in Multiple Regression Analysis to Predict Hearing Officer Decision (Outcome) in Due Process Hearings

\begin{tabular}{llll}
\hline Variable ID & Variable Name & Content & Range \\
\hline
\end{tabular}

I. Variables Describing Selected Child Characteristics

03

$\begin{array}{ll}2 & =1972 \\ 3 & =1973 \\ 4 & =1974 \\ 5 & =1975\end{array}$

Chronological Age Rounded to $\quad 0-20$

06

Age

the Nearest Year

Sex

$1=$ male

2 = female

07

Child Previously

$0=$ no

$1=$ yes

in Special

$0=$ not yet school age

Genl 8

Normality of

Child's

$1=$ normal classroom

Placement

$2=$ transition class or resource room

3 = classroom for LD, SED, BI, EMR or physically handicapped

$4=$ combined EMR-TMR class

$5=$ TMR classroom

$6=$ low trainable classroom

$7=$ SMR-PMR class

$8=$ temporary homebound instruction

$9=$ exclusion

Fac 8

Restrictiveness
of Placement

$0=$ none

$1=$ classroom in regular public school

$2=$ public school classroom building unspecified

3 = classroom run by I.U. in regular public school

$4=$ classroom in special public district education building

$\mathbf{5}=$ classroom run by I.U. in I.U. building

$6=$ private facility

$7=$ state instruction

II. Variables Describing Parent Performance

Parent

Involvement

with School

Prior to Hearing
Sum of scores for items V48 to V63 after weighting for difficulty of making type of contact ${ }^{a}$

$0=$ no on $\mathrm{V} 48-\mathrm{V} 63$

a Items may be found infra app. B, p. 117. 
Parent Involvement Preparing for Hearing Independent of School

01

505

506

Genl 9

Fac 9

509

Hearing Open or Closed

Number of Ex-

hibits Parents

Enter

Restrictiveness

Parents Want

Degree Parent
$1=$ yes on V48, V49, V54, V57, V58, V60-V63

$2=$ yes on V51, V52, V55, V59

$3=$ yes on V $50, \mathrm{~V} 53, \mathrm{~V} 56$

Sum of scores for items V64-V81 after weighting as follows:

$0=$ no contact

$1=$ nonprofessional contact

$4=$ professional contact

$9=$ professional contact, written evaluation obtained

$0=$ closed

$0-1$

$1=$ open

$0=$ no

$1=$ yes

Case for Parents

Sum of scores for items V40-

$\mathrm{V} 42^{\mathrm{b}}$

$0=$ none

Sum of scores for items V43-V45, $\mathrm{V} 47 \mathrm{c}$

$0=$ none

Same as Genl 8

Same as Fac 8

Demands Tax

School Re-

sources

Sum V89-V91d

For V89 Program Location

$0=$ not relevant

$1=$ program exists in district

$2=$ program exists in I.U. or state facility

$3=$ program exists in private facility

$4=$ program must be created

For V90 Transportation

$0=$ not relevant

$1=$ readily available

2 = available but inconvenient

$3=$ not available, transportation must be purchased

For V91 Support Services

$0=$ not needed

$1=$ readily available

$2=$ partially or infrequently available

$3=$ not available, must be created

Items may be found infra app. B, p. 117.

c Items may be found infra app. B, p. 117.

d Items may be found infra app. B, p. 117. 
Effectiveness of Parents' Questioning

87

04

IUPOP Intermediate

IUMIC Intermediate

IUED

504
Overall Quality of Parents' Presentation volvement with parent prior to the hearing

Lawyer Directs Case for School

Number of Exby School Number of Wit-

$1=$ no questioning

2 = questioning, but not challengingly

$3=$ questions, challenges, but not within coherent framework

4 = questions, challenges within narrow framework

$5=$ questions, challenges, within broad framework

$1=$ no presentation

$2=$ presentation subjectively based

3 = presentation objectively based but not adequately supported

$4=$ presentation objectively based, supported but not well organized

$5=$ presentation, objectively based, supported, well organized and argued

III. Selected Variables Describing School Districts unit population unit income level

District Urbanization

$1=$ urban school district

2 = suburban school district

$3=$ rural school district

Mean population of counties making up each I.U.

Weighted average of median incomes of counties making up I.U.

Weighted average of median educational achievement in years, of people over 25 in counties making up I.U. unit educational level
$1-5$

27,967 to $1,948,608$ (people)

7,596 to 12,747 (dollars)

10.90 to 12.20 (years)

\section{Selected Variables Describing School District Performance}

Sum of scores for items V29V31e $0=$ no

$1=$ yes

$0=$ no

$1=$ yes

Sum of scores for items V15-V17f $0=$ none

Sum of scores for items V18-V22g nesses Em- 
ployed by

School

Genl 10

Placement

School Wants

Fac 10

Facility School

Wants

503

36

Degree to which

School Ad-

dresses PARC

requirements

Overall Quality of School's Presentation
Same as Genl 8

Same as Fac 8

Sum of scores for items V23V28

$0=$ no

$1=$ yes

Same as V87

V. Selected Variables Describing Hearing Officer Affiliation and Behavior

Hearing Officer

Affiliation

Hearing Officer

Does Most of the Questioning

Degree to which Hearing Officer

Adheres to PARC Requirements

Hearing Officer Partiality

Hearing Officer Decision (Outcome)
$1=$ employed by school district

2 = employed by I.U.

$3=$ employed by college or university

$0=$ no

$1=$ yes

Sum of V94, V96-V99i

$0=$ no

$1=$ yes

Sum of V100-V105j after weighting as follows:

1 = totally biased toward school

2 = leaning toward school

$3=$ impartial

$4=$ leaning toward Parent

$5=$ totally biased toward Parent

$1=$ complete loss for Parent

$1-5$

2 = partial loss

3 = compromise

$4=$ partial win for Parents

$5=$ complete win for Parents

h Items may be found infra app. B, p. 118 .

i Items may be found infra app. B, p. 118 .

j Items may be found infra app. B, p. 118 . 


\section{Appendix B}

\section{Selected Variables}

507. Parents involvement with school prior to due process hearing (prior to the hearing, which of the following people were consulted by the parents?)

48. Principal.

49. School psychologist

50. Other teachers

51. Classroom teacher (child's present)

52. Classroom teacher (child's past).

53. Classroom teacher (child's proposed)

54. Guidance counselor.

55. Director of special education (I.U. or district) i.e., person who is in charge of special education .

56. Attorney for school

505. How many exhibits in each of the following groups were submitted as evidence by the parents?

40. Diagnostic exhibits

41. Exhibits relating to child's performan in

42. Exhibits pertaining to child's family background and home performance $\ldots \ldots \ldots \ldots$

506. How many witnesses in each of the following groups appear for the parents?.... -

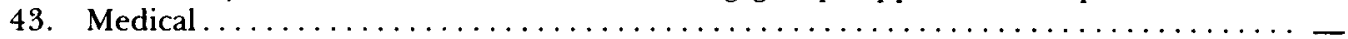

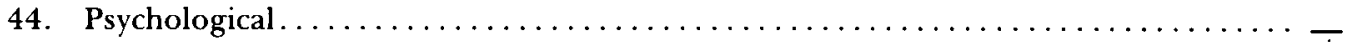

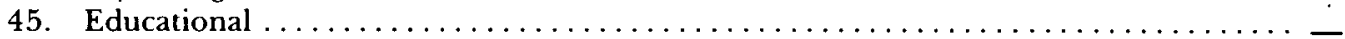

46. Nonprofessional .....................

47. Other professional (list below and give total to right)

509. Degree to which demands of parent's tax school resources

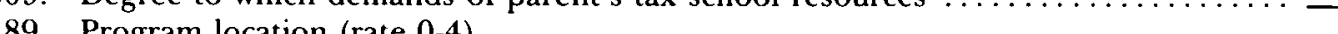

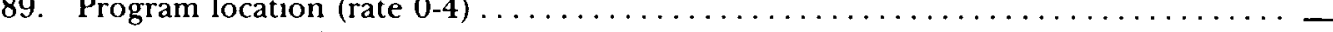

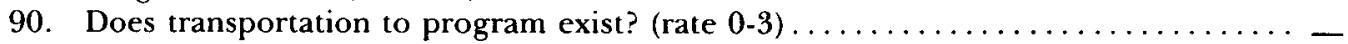

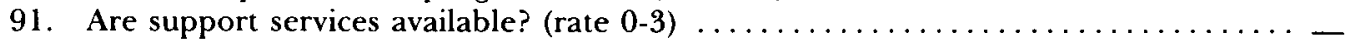

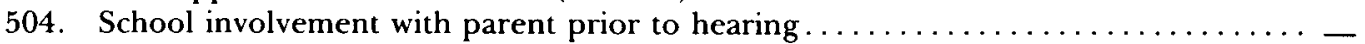

29. Has the school's evaluation been explained to the parents? ..............

30. Has procedure by which school arrived at placement decision been explained to the

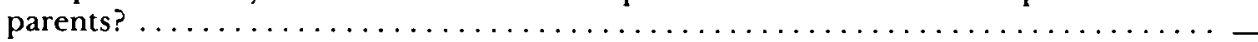

31. Has content of program child will be in been explained to parents? ...........

501. How many exhibits in each of the following groups were submitted as evidence by the school district or intermediate unit?

15. Diagnostic exhibits

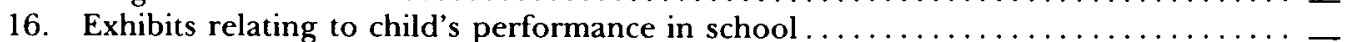

17. Exhibits pertaining to child's family background and home performance ........ -

502. How many witnesses in each of the following groups appear for the school? ..... -

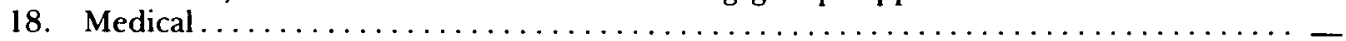

19. Psychological. ......................

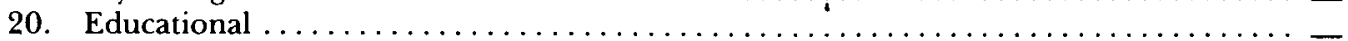

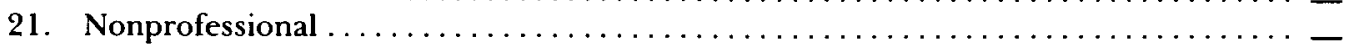

22. Other professional (list below and give total number to the right) $\ldots \ldots \ldots \ldots \ldots$ 
503. Degree to which the school addresses the issues of the consent decree $\ldots \ldots \ldots \ldots-$

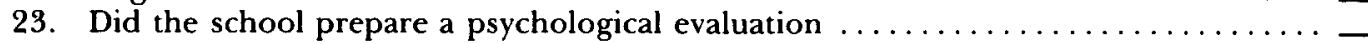

24. Was the school's evaluation broad (versus narrow)? ..................

25. Did the school prepare a prescription which follows from their evaluation?

26. Was the school's prescription flexible and individualized (versus rigid and narrow)? -

27. Did the school propose a program which followed from the prescription? ....... -

28. Was the school's program created to meet individual needs? .............

510. Degree to which the hearing officer adheres to the requirements of the consent

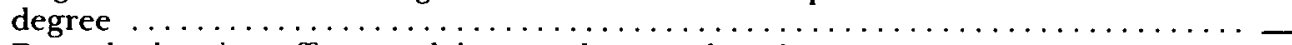

94. Does the hearing officer explain appeals procedures? $\ldots \ldots \ldots \ldots \ldots \ldots \ldots \ldots \ldots$

96. Does the hearing officer attempt to find out from the parent or school if there is a need for the proposed change? (i.e., does he/she inquire into the quality of the evaluation?)

97. Does the hearing officer try to find out whether there is a fit between evaluations and prescription? Does the hearing officer examine the relationship between the evaluation and the prescription?

98. Does the hearing officer try to find out if the program is adequate to meet the prescription? . .

99. Does the hearing officer address him/herself to the concept of normalization? ... -

511. Degree to which the hearing officer attempts to run an impartial hearing (each question should be addressed twice, once using the bias scale and once as yes/no)

101. Does the hearing officer refuse to admit arguably relevant testimony ........... -

102. Does the hearing officer admit evidence after expressing doubts about admissibility? -

103. Does the hearing officer make statements or inquiries reasonably necessary to clarify or respond to statements of parents and/or school, and/or their witnesses?

104. Does the hearing officer make statements or inquiries necessary to ensure that parents' or school's stories come out completely?

105. Does the hearing officer show anger, impatience, or sarcasm toward either side?... - 